\title{
Sustainability science as if the world mattered: sketching an art contribution by comparison
}

\author{
Michael H. Pröpper ${ }^{1}$
}

\begin{abstract}
Here, I investigate some of the potential contributions of art to the emerging field of sustainability science. First, the involvement of sustainability thinking in art is massively increasing. Second, there is a line of interactions between art and science that do not necessarily take sustainability as their content, at least in an ecological sense. Third, there are a considerable number of examples of sustainability science projects that are intended to link knowledge to social action without involving art. I exemplarily compare these different combinations to gain a concise overview of and differentiate between current activities and to identify some shortcomings and potentials of various contributions. The utilitarian and rather pragmatic question I ask is: What does art have to offer to sustainability science that the latter currently lacks? This question is asked from my own anthropological viewpoint, that of cultural and social science, partaking in sustainability science. I use empirical insights from sustainability projects in Africa that I took part in, which specifically dealt with sustainable land management. I blend these findings with results from a broad literature review and a comparison of multiple existing art projects. I show that a sustainability science that aims to matter to people and that takes its core tenet of linking the produced knowledge to sustainable social action seriously while facing an existing crisis of agency and knowledge would strongly benefit from opening to an experimental and experiential approach to knowledge production that explicitly includes processual, affective, and sensory types of knowledge, imaginative agency, and conceptual forms of interaction.
\end{abstract}

Key Words: Africa, agency, art, comparison, imagination, knowledge production, sustainability science

\section{INTRODUCTION}

In attempting to link knowledge to social action, academic sustainability science has so far largely been oblivious to the potential contribution of art. Salient journals in the field do not enlist artists as their potential contributors or readers (e.g., Sustainability Science, Sustainability, Sustainable Development; see also http://www.futureearth.org/who-we-are). Founding articles of this "vibrant arena that is bringing together scholarship and practice, global and local perspectives from north and south, and disciplines across the natural and social sciences, engineering, and medicine" (Clark and Dickson 2003:8060) have also not explicitly emphasized the importance of art as a contributing practice (Clark and Dickson 2003, Komiyama and Takeuchi 2006, Bettencourt and Kaur 2011, Kates 2011, Miller 2013). However, in the face of massive engagement of artists in the field of sustainability knowledge production and action (Weintraub 2012, Klingan et al. 2015, Neal 2015), it must be asked if the approaches are to remain separated and if sustainability science might not benefit from (taking a closer look at) art (and vice versa).

Sustainability science is a massively growing yet somewhat heterogeneous field still struggling to merge natural science and social science approaches (Schoolman et al. 2012) despite considerable efforts to overcome stubbornly persistent, but often outdated dichotomies of culture and nature (Descola 2013). Sustainability means to live a lifestyle adapted for permanence that ensures the coexistence of human economic needs and activities and the preservation of the environment, without compromising the opportunities of future generations (Komiyama and Takeuchi 2006, Caradonna 2014). In recent times, in which an environmentally detrimental human footprint is being acknowledged (Rockström et al. 2009, Borucke et al. 2013, Hoekstra and Wiedmann 2014), it has become a normative goaloriented concept denoting the need to counterbalance (Caradonna 2014) and alter human behavior on the planet during a period called the Anthropocene (Steffen et al. 2011) or the post- normal age (Funtowicz and Ravetz 1995). The most salient scientific nuts to crack seem to be those involving common and complex subjects such as social-ecological systems (Berkes et al. 2002, Ostrom 2009), understanding ecological and social mechanisms for resilience (Holling and Gunderson 2002), conservation and the revaluation of ecosystem services (Daily et al. 2009, De Groot et al. 2012, Bateman et al. 2013, Büscher et al. 2014), and sustainable consumption (Jackson 2006, Hoekstra and Wiedmann 2014) to name only a few. All approaches attempt to find novel ways of understanding the inextricable link between humans and other living beings, and societies and their functions and interactions with a threatened environment (Lenton et al. 2008).

Sustainability science is both basic and applied; it is part of a societal techno-political solution-seeking process (e.g., through climate governance, ecosystem services management, reducing emissions from deforestation and forest degradation [REDD+], community-based natural resource management), but it is also an attempt to understand the conundrums of individuals' involvement in processes of culture and economy, and thus offer potential solutions prompting or facilitating pro-environmental behavioral change (Stern 2000, Miller 2013; https://www. globalactionplan.org.uk/). The output largely takes the form of providing knowledge for the scientific community and the public, plus counseling another societal decision-making segment, i.e., policy, through text-and graph-based representations of scientific results. Academic sustainability science thus often does not have to take responsibility for a successful real-world transferral of results. However, transdiciplinary work involving practitioners and various stakeholders is increasingly being advocated to close this gap (Hirsch Hadorn et al. 2006, Popa et al. 2015).

There is a slowly growing (self-)critique of academic sustainability sciences' lack of reflexivity, awareness of complexity, and ability to take responsibility for its outcomes (Grunwald 2004, Miller 
2013, Büscher et al. 2014). Some authors have problematized the lack of incentives "to enhance the ability of sustainability scientists to draw from multiple fields"(Miller 2013). The question of how sustainability science will address complex social or cultural factors that limit sustainable decision making remains largely unanswered (Miller 2013). In the subfield of ecosystem services science too (Daily 1997, Daily and Matson 2008), which I will exemplarily touch upon below, the main concept has been accused of obfuscating complexity (Norgaard 2010). More broadly speaking, Pedersen and Hendricks (2014) have emphasized that (because of a transformation of incentive and reward structures such as financialization, competition, marketization) in most countries, science runs the increased risk of producing "bubbles," but no solutions for complex settings. In addition to these voices, there is a growing awareness of the necessities of improved environmental communication (Lindenfeld et al. 2012), reflexivity (Grunwald 2004), and transformative science (Grunwald 2015), and increasing recognition of the failures of environmental governance and of the need for a cultural shift and transformative change in the global economy (Hoekstra and Wiedmann 2014), including the challenge of awakening the "sleeping giant" of the individual consumer (Fuchs and Lorek 2005, Grunwald 2014).

The causes of such shortcomings are diverse and cannot be dealt with exhaustively here. Regarding the link between knowledge and social action, which is one of the core tenets of sustainability science, the issues of knowledge and agency and the real-world applicability of this knowledge seem to be the main elephants in the room, and the main points where I suggest that art might be able to play a role.

Art is a highly multifaceted societal subsystem, "a practice which, since it transects the realms of knowledge, morality (politics), beauty and daily life, has its own dynamic and logic that cannot be corralled into traditional academic structures" (Borgdorff 2009:12). It differs from scientific approaches in that its protagonists enjoy more freedom because art is not burdened so strongly with rigid rules of replicability, goal orientedness, or purely utilitarian, socially reproductive functions (Gablik 1997). The individual experience of the world as experienced by the artist (s) is rather explicitly emphasized over the social reproducibility. However, serious art is also a practice of research (Finley and Knowles 1995, Johnson 2010, Borgdorff 2011, Wesseling 2011; http://www.societyforartisticresearch.org/jar/) to capture the essence of the world in novel and eye-opening ways. The main targets of "art for sustainability" are to find knowledge and practices that avoid processes and behaviors that are detrimental to planetary living conditions and to promote decisions and behaviors to the advantage of future generations. However, there is a self-containedness paired with skepticism about the knowledge generated by sustainability science: "Science tells us things but it is art that helps us take them on board at a deeper level. Creative practice has shown how we can break through prejudice, apathy, economic pressures and blind spots to catalyze a transformation of culture, attitudes, and behaviours" (Allen 2015:26). This can be read as an implicit critique of theoretical "as-if" solutions (Hiller 1996, Neal 2015), which resemble what Pedersen and Hendricks (2014) have called science bubbles. What the art world is emphasizing instead is a direct social interaction with stakeholders in mutual solution finding through bodily, sensory, and intuitive involvement (see also Scheffer et al. 2015); the aesthetic and emotional dimensions of actors; and the intrinsic values of connection and cooperation (Neal 2015).

In this situation, we find very few examples of attempts to approach a broader picture by merging art, sustainability, and science (https://www.clisap.de/research/ia:-integrated-activities/ usi/visiting-artist-researchers-3/). On the social science side, the exhibitions and digital-collaborative art and science projects that Latour $(2002,2013)$ has thought up with artists to renew the political-ecological through the spirit of art and science come to mind (http://www.bruno-latour.fr/node/333, http://zkm.de/en/ event/2002/05/iconoclash). Rather salient on the other side is the massively increasing involment of sustainability thinking in art (Klingan et al. 2015, Neal 2015), yet without necessarily addressing the work of academic sustainability science. In addition, there is a line of art-and-science interactions, without necessarily investigating the subject of sustainability, at least in an ecological sense (Wilson 2013, Miller 2014). Lastly, there are science and sustainability projects that bear critical enquiry as to their artfulness.

Here, I compare these different approaches for two purposes: to gain a concise overview of current activities and to identify both shortcomings and potentials for reconcilitation. The utilitarian and rather pragmatic question I ask is: What does art have to offer to sustainability science that the latter currently lacks? This enquiry will be made from my own anthropological viewpoint, i.e., that of the cultural and social science perspective, partaking in sustainability science (Pröpper and Haupts 2014, Schnegg et al. 2014). I use empirical insights into sustainability projects in Africa specifically dealing with sustainable ecosystem services and land management. I then blend these findings with results from a literature review and a comparison of exisiting projects to sketch out the concept of an artistic contribution to sustainability science.

\section{COMPARISON}

\section{Art and sustainability}

There exists a large and thriving sustainability art movement using a multitude of methods and materials. I highlight this by examining few recent landmark publications (Weintraub 2012, Klingan et al. 2015, Neal 2015; I do not explicitly consider another highly interesting subsection called Bio Art, focusing on the possibilities and dangers of biotechnological advancement [Myers 2015, Vaage 2016]). In these publications, various artists reflect on the role of art in society to date and find that art not only pursues its more conventionally recognized aesthetic, decorative, descriptive, performative, or social functions, but also takes on a role as an active agent of sustainability in highly diverse ways.

Facing the observation that humankind over the last 300 centuries has gained a geohistorical dominance of the planet that has led to a new era called the Anthropocene (Steffen et al. 2011), the Haus der Kulturen der Welt (House of World Cultures; HDK) in Berlin, Germany set out to do foundational research by means of both art and science. The HDK created a platform for dialogue that produced exhibitions, lectures, conferences, films, and publications, among them a large three-volume book called Textures of the Anthropocene (Klingan et al. 2015). The volumes are titled Grain, Vapor, and Ray to symbolize material and immaterial processes of a world in change and explicitly 
point at the sensuous qualities of the particluar, the volatility of metabolic processes and phase changes, and the radiant transportation of energy. As guiding principles, these qualities subsume textual dialogues between scientists and artists based on a rereading of historical texts. There is not adequate space here to document the complexity of emerging interactions. However, the most interesting aspect of this rather theoretical work is the attempt to open disciplinary borders and subjects of thinking to a new understanding of processes and imagination that involves science and art on an equal footing.

In a much more application-oriented compilation, Neal (2015) asks for art "as if the world mattered" and offers a multitude of participatory and celebratory examples of art engagements with the world in search of practical real-world sustainability. A key that is emphasized in many examples is the potential of art to provide direct experience of situations and contexts. Two examples may highlight this contribution.

In 2013, five Latvian artists undertook a live social experiment called Testing Transition by moving to the countryside for 10 days without food, money, or credit cards. The purpose of the rulebased experiment was to reskill the artists and the surrounding community in nonmonetary exchange. The artists would offer their skills in exchange for food. The experiment, documented through diaries and video, made it clear as a direct experience to all participants that reciprocity and mutual trust in times of crisis are of immediate value. Additionally, the artists returned home loaded with bags of vegetables and food (Neal 2015:212). The second example, a one-day art event called Waterproof, took place at the river Avon in the United Kingdom at the same time. Several artists met for one day of walking, swimming, rope-swinging, kayaking, reflection, silence, stories, singing, observations, listening, discussing, food, warmth, and sociality to explore the multiple meanings of the element of water for humans. As with many other artists' performative practices, this is a simple example of a holistic approach to experiencing a multitude of environmental connections that goes far beyond the distanced methodology of observation, interviewing, and description, and involves emotions, sociality, and sensuality (Neal 2015:237). As such, Neal (2015) advocates such playful engagement as opening up possibilities of seeing the world differently as "circuit breakers of tragedy" and a re-enchantment of relocalized culture (Gablik 1997).

In her compilation of 47 contemporary eco-art approaches across the globe, Weintraub (2012) summarizes several qualities of art in the face of the current environmental crisis: artists' astute communication skills, art's inspirational capacities that can activate behavioral changes, art's capacity to support and inspire engagement for policy reforms, art's creative ingenuity directed to life-sustaining problem solving, and art's function as a cultural conscience, all of which can support custodial care for the planet. With the collection of eco-art examples, she emphasizes that many eco-artists challenge an understanding of nature as existing independently of human activities (a premise that is being used to justify detrimental behavior) and "apply their communication skills to expand the definition of nature by incorporating human populations, all human technologies and all the products of their imaginations" (Weintraub 2012:prefix). As such, they take on varied roles as shepherds, technical designers, managers, healers, emissaries, or avengers to tackle a multitude of fundamentally ecological issues such as extinction, energy balances, habitat losses, etc. This will become more concrete by examining a few examples.

The Beehive Design Collective is an activist arts collective consisting of anonymous "bees" dedicated to "cross-pollinating the grassroots" by creating collaborative, anticopyright images for use as educational and organizing tools. They describe their work as word-to-image translations of complex global stories that affected communities share with them through conversations (https://www.facebook.com/beehivedesigncollective/). A look at the project The True Cost of Coal illustrates how the group works with extended field research, interviews, story sharing, and community meetings to ally with Appalachian coalfield inhabitants fighting mountaintop-removal coal mining, a highly destructive practice. The outcome of this participatory process is not a text but one large graphic poster that can be unfolded and which graphically tells the story of exploitation and extraction, toxic contamination, and privatization of resources (https://store. beehivecollective.org/collections/the-true-cost-of-coal). This anonymous and anticopyright graphic communication method forms the basis for an interactive campaign that includes the Internet and social media and also picture-lectures and visits to fairs, protest rallies, and schools (Weintraub 2012:129).

The Australian artist Natalie Jeremijenko has a background in biophysics, English, neuroscience, and mechanical engineering, and is a rare example of an artist merging profound expertise in several fields. Her work is about new technologies being used to drive sustainable social change and "about creating interfaces that draw people into the environment and get them to reimagine collective action" (Berger 2006). One exemplary project out of a wealth of comparable ones is OOZ, the word Zoo read backwards, in which she created a series of sites where animals (fish, mussels, doves) and humans interact through electronic devices. The sites provide humans with a set of actions, the animals provide reactions, and these couplets add to a collective pool of observations. With this and multiple other projects of her Environmental Health Clinic (https://www.facebook.com/ xclinic/app/102076423177195/) that critically question the interrelationship of humans and nonhumans in ecosystems under threat, she creatively attempts to address a crisis of agency in public and individual environmental action (https://www.ted. com/speakers/natalie jeremijenko), and thus challenges the intellectual and moral authority of anthropocentric science and the meta-narrative of unidirectional transformation (Weintraub 2012:210).

The selected examples only offer a narrow view of existing activities. However, real-time social experiments, collective experience exercises, socially engaged collaborations with graphic output, and the creation of tangible interfaces between people and the environment indicate an abundance of creative forms of cooperative knowledge production.

\section{Attempts to reconcile art and anthropology}

I next use the example of anthropology, which is certainly part of sustainability sciences (Abel and Stepp 2003, Lockyer and Veteto 2013, Brightman and Lewis 2017) to highlight some aspects of a current convergence between science and art (without necessarily being sustainability oriented). While there is a strong mutual 
appeal between art and anthropology, encounters with art mainly take place in the socio-political domain, and there is little involvement of ecological thinking and aspects of sustainability. Social questions, e.g., about the politics of equal and just participation, marginalization, hegemoniality, gender and power differentials, and criticism of the politics of collaboration (Bishop 2012, Göltenboth 2015), seem to be appealing to artists, as relational aesthetics and socially engaged participatory art are important contemporary strands (Kester 2011).

In recent years, there has thus occurred a massive renaissance of encounters between art and anthropology. To approach more sensually holistic ways of understanding and representing different realities in a globally transforming world, several contemporary projects and publications deal with interlinkages between art and anthropology, and even more so between art and ethnography, anthropology's central practice (Svasek 2007, Pink 2009, Pink et al. 2010, Schneider and Wright 2010, 2013, Latour 2013, Grimshaw and Ravetz 2015). Edited volumes (Marcus and Myers 1995, Schneider and Wright 2006, 2010, 2013, Baxstrom et al. 2008, Cox et al. 2016), special journal issues (Pink et al. 2010, Rutten et al. 2013, Pröpper 2015b, Blanes et al. 2016), blogs and collaborative projects (http://artpologist.com/, http://www.abdn. ac.uk/research/kfil, http://field-journal.com/, http://www.anthropologiesof-art.net/), interdisciplinary institutes (http://sel.fas.harvard.

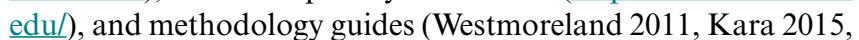
Elliott and Culhane 2016) indicate activities in this thriving field of interaction and collaboration. Often, book and journal compilations join products by artists and anthropologists side by side; likewise, works are increasingly emerging from people with hybrid identities, i.e., people who do both anthropology and art (Schneider and Wright 2013).

Two decades ago, Foster (1995) observed that anthropology was becoming especially popular among artists as a science of alterity because it takes culture as its object and is open to self-critique and reflexivity. As part of anthropology's attractive selfreflexivity, there are multiple debates certainly of great interest for contemporary artists. I am thinking of debates about the (im) possibilities, adequacies, ethics, and politics of representing self and other (Clifford and Marcus 1986, and a myriad of subsequent publications), questions of subjectivity vs. intersubjectivity and structure vs. agency (Giddens 1979, Gell 1998), whether anthropology is a science at all or an art in itself (Carrithers 1990), enquries into the materiality and processuality of the human predicament (Ingold 2000, Miller 2005, Wimmer 2005, Carrier and West 2009), and recent debates about the merging of culture and nature in times of the Anthropocene (Latour 2017). Ethnography, characterized by the direct encounter and "withinness" of the researcher in real-life sociality, culture, and politics, seems to have intrigued artists of late and has even caused an ethnographic turn in the arts (Coles 2001, Grimshaw and Ravetz 2015). Likewise, Foster (1995:304) has found a certain selfidealized "artist-envy" among anthropologists in which "the artist becomes a paragon of formal reflexivity, sensitive to difference and open to chance, a self-aware reader of culture understood as text."

However, apart from such mutually intriguing idealizations, what is the real and critical contribution of art to anthropology as a science (Carrithers 1990)? I highlight three interlinked aspects: experimentation and collaborative knowledge production and representation, the involvement of sensuality, and the matter of linking knowledge to agency and action.

Today anthropology is still largely a word- or text-based, descriptive, comparative social science. Scientists collect data to produce ethnographic representations of complex cultural contexts. Naturally, anthropologists have long sought practices and methods with which to broaden their repertoire of ethnographic representation beyond texts (Cox et al. 2016), yet there are different positions with regard to the limits of experimentation and the convergence of art and ethnography (Clifford 1988, Grimshaw and Ravetz 2015). The question is whether artistic methods should be used for creative and aesthetic purposes or as proper additional methods of investigation, i.e., not only to colour but to deepen anthropological ethnographies. Ultimately, this is a question about the boundaries and division of labor between science and art, but it is also related to the meaning of aesthetics as a research practice (Grimshaw and Ravetz 2015). A rather classical dichotomy of clearly distributed roles (art doing practical-aesthetic experiments without ever claiming to produce more than direct sensations differing among recipients; sciences producing an aesthetically limited written analysis, the etic and intersubjectively intelligible, collectively accountable, and "ethically correct" view) might result in a denial that reality is more highly faceted.

Within the discipline of anthropology, several voices have thus been raised in favor of increased collaboration and experimentation (Schneider 2008, Strohm 2012, Elliott and Culhane 2016). Focusing on many practice-based examples, Schneider and Wright (2006, 2010, 2013; Schneider 2008) have discussed the distinctions and fuzzy borders between artists' and anthropologists' practices and have advocated an artethnography based on cross-fertilization, dialogue, appropriation, and collaboration, not only in the visual but also in other domains integrating other means of representation such as exhibitions, photo essays, performative elements, blogs, and soundscapes (Heuson 2015). Ingold (2008) has suggested that anthropology should investigate the world also in an experimental, forwardlooking, self-reflexive, and philosophical manner. Describing the anthropological scientific endeavor as thoroughly experiential, sensual, and improvisatory, and based on practical processual acts of making, he compared it to art (Ingold 2013, 2016). He has also presented writings and experiments relating to a graphic and motive anthropology (Ingold 2001, 2007, 2010, Ingold and Hallam 2007; see also Ramos 2015) that emphasizes a different type of emergent and embodied knowledge.

The most far-reaching step so far seems to be the "ethnographic conceptualism" that Ssorin-Chaikov (2013) has suggested. He is explicitly asking for mutual gains between anthropology and art by bringing in a conceptualism inspired by the artist Joseph Kosuth (1991). Ssorin-Chaikov (2013:6) argues for "anthropology as a method of conceptual art but also, conversely, to to the use of conceptual art as an anthropological tool" and ethnography conducted as conceptual art. He is occupied with the limits or failures of knowledge that are in constant flux, the unknown that surrounds the situational manufacturing of ethnographic fact discovery, and suggests an experimental way of manufacturing social reality instead of merely depicting it. Ultimately, the goal 
is an approach to the complexity of constantly emerging knowledge of people experiencing rapid transformation that integrates the performative methodological involvement of audiences similarly to conceptual art. Exemplarily, this has been shown by Ringel (2013), who undertook three different types of conceptual interventions in Hoyerswerda, a rapidly shrinking city in eastern Germany. By writing a weekly newspaper column, organizing an anthropological youth camp, and inventing an artistic paint-block project in which citizens turned to artists to recreate an industrial building before its deconstruction, he joined ethnographers and informants as epistemic collaborators in the production of knowledge. The crucial point about this artinspired conceptual and interventive field-lab is the stimulation of reflexive repercussions (e.g., public comments on the column) and new affective stances regarding the city's inescapable decline that produced surprising and previously untapped ethnographic insights and nonrepresentational experiential knowledge that took the challenge of the contemporariness of the local economy of knowledge seriously (Ringel 2013).

The second aspect approaches the challenge of adequate scientific representation of realities through a renewed focus on the senses. It seems that in their contemporary struggles to deal with the unspeakable, unrepresentable aspects of the human condition, i.e., the complex interaction of the sensual self with the world (Howes 2003, Smith 2010), anthropologists increasingly admire artists for their liberty of expression beyond merely textual representations (Cox et al. 2016) and tend to learn from the latters' practices. The immersive multisensorial products of the Harvard Sensory Ethnography Lab (http://sel. fas.harvard.edu/) producing sensually radical filmic experiences of ethnographic content, such as the film Leviathan filmed on a U.S. fish-trawler (http://www.arretetoncinema.org/leviathan/), might be read as only one current example of a new concern with the senses, a "sensory turn," in anthropology (Rutten et al. 2013). Pink (2009) has offered a guidebook of how to do "sensory ethnography."

The crucial point about all these attempts is that they aim to close a gap between the researchers' sensual involvement in the researched context, the distanced role of an observer, and the written analytical product that is being produced at the desktop after the end of fieldwork. Susan Hiller, an anthropologist who later turned to art, experienced great discomfort in the role of the observer and became an artist to "find a way to be inside all [her] activities" (Einzig 1996, Hiller 1996). In fact, the detachment of the scientist from his or her object of study, the unreachable claim for objectivity, and the lack of recognition of involvement are all serious matters that have been debated for a long time (Jackson 1998, Fabian 2014). Contrarily, Hiller (1996:24) postulates that the artist, like everyone else, is an insider whose work depicts biographically determined social conditioning: "Artists' work does not allow discontinuities between experience and reality, and it eliminates any gap between the investigator and the object or situation investigated." Consequently, she found the role of the participant observer disturbing because of the absence of a "passionate commitment to the values and goals of the people one observed. Fieldwork did not provide revelations into the nature of any 'ultimate' reality behind the varying sets of perceptions one learned of. It was just an exercise in observation and limited social interaction" (Hiller 1996:18).
The Austrian artist and sociologist Christina Lammer advocates "artistic research" and uses the term "empathography" for a related focus on holistic experience (Lammer et al. 2012). She has taken an intermediate position between art and biomedical science, where much of her research has been concerned with the aesthetic dimensions of surgery. Her work takes place in hospitals and clinics and combines sensory ethnography with video, performance, and body art. She focuses on embodied emotion and sensory interaction between patients and physicians during the course of medical treatment and produces holistic accounts of encounters that include, e.g., sensual touch, shame, and vulnerability. By exploring the relationship between sensory ethnography and artistic research, she expands the frame of conventional research toward intimate, empathetic, subjectobject encounters in clinical situations (Pröpper and Lammer 2015).

This last point relates to the link between scientifically produced knowledge and action, i.e., the fact that coproduced knowledge regarding sustainability (e.g., recommendations for sustainable behavior) must be turned into action. This includes the whole aspect of transdisciplinarity, which takes as its central claim that knowledge happens to be coproduced between academic and nonacademic stakeholders (Hirsch Hadorn et al. 2006, Schmidt and Pröpper 2017). Although anthropologists work closely with local stakeholders and have a certain closeness to artists, they are not automatically experts in transdisciplinarity and sustainable collaborative knowledge production. In such processes, artists could be involved just as well as any other stakeholders. A way forward would thus be to go beyond the methodology of participant observation to come to a more practical involvement in the mutual generation and coevolution of knowledge and thus the emergence of applied practical behavior.

In sum, the example of anthropology is certainly not directly transferable to other disciplines, yet it offers some examples of a productive confluence of science and art worth considering. In short, the contributions of art involve an experimental approach to knowledge production that explicitly includes affective and sensory types of knowledge. Art contributes forms of interaction that allow for unforeseen types of real-time repercussions and a less distant, compassionate commitment (in the sense of empathography) to the subjects of study.

\section{Sustainability science in Africa: linking knowledge to action?}

Inext compare the outcomes of the above discussion with research on land-use change and sustainable land management in Africa. I use the example of a transdisciplinary research project on sustainable land management in southern Africa called "The Future Okavango" (TFO), which ran from 2009 to 2015 (Pröpper et al. 2015; http://www.future-okavango.org/index.php). As part of a global initiative of the German Ministry of Education and Research (Eppink et al. 2012), the multidisciplinary project's goal was to provide a holistic assessment of ecosystem services and their interdependencies with sustainable land use and resource management in the Okavango Basin, located within and crossing the borders of Angola, Botswana, and Namibia (Oldeland et al. 2013). The outcomes of the project were destined for rather different yet interlinked scales of this transboundary socialecological system and its multiple stakeholder audiences. Apart from critical academic contributions to the ecosystem services 
debate (Pröpper 2015a, Röder et al. 2015), they included: (1) baseline data assessments closing regional data gaps (e.g., on hydrology, fire management), (2) policy recommendations (e.g., water governance, forest management, soil fertility improvement, revaluation of cultural ecosystem services), and (3) scenarios for potential future pathways of management (Pröpper et al. 2015). The output of the project (reports, flyers, posters, films, data and mapping DVDs, talks and presentations) was handed to multiple audiences over the course of the project and during a final dissemination tour and is available in the countries involved and via the Internet. Consequently, the responsibility for application of this academic "knowledge about the system" remains with political and local actors who had been at least partly involved in the project.

Especially looking at the scenarios for potential future pathways of management in the African context, one can compare a conventional approach that was applied in the TFO case (Pröpper et al. 2015) with additional artistic methods such as participatory painting that have been used, for example, by Johansson and Isgren (2017) in Tanzania. The aim of scenarios is to investigate and describe possible futures to "explore socioenvironmental effects" and prepare decision-making strategies (Pröpper et al. 2015:109, Johansson and Isgren 2017:4). Importantly, scenario building is a participatory exercise that should integrate the perspectives and lived experiences of the people involved in the social-ecological system under investigation. In the classical TFO case, scenarios were built by an interdisciplinary expert team consisting of 26 researchers from all subprojects, disciplines, and involved countries. This team additionally made use of information from 90 interviews with stakeholders from local, regional, and national scales from all three African countries (Domptail and Mundy 2013). The outcome is a set of different and comparable storylines, i.e., combinations of texts, graphs, and photos, for the local and the Okavango Basin level. However, there was no methodology used to visualize the future visions of local stakeholders. Participatory research that uses experimental artistic methods to integrate stakeholders' perspectives into scenarios is nascent, yet Johansson and Isgren (2017) have used local village painting workshops to collaboratively create illustrative images of the past, the present, and the projected future with the help of a professional artist. It can be clearly stated that the TFO scenarios would have benefitted from such artistic approaches to stakeholder involvement.

Additionally, the results of an in-depth analysis of the project's transdisciplinary success have revealed several sucesses but also highlighted difficulties in achieving the goal of transdiciplinarity, the involvement of stakeholders in all phases of the research process (Schmidt and Pröpper 2017). The empirical "reality checking" of an abstract concept showed that, in fact, such largescale sustainability projects operate within a highly politicized and often hierarchical landscape with diverse stakeholders, structural asymmetries, and multiple expectations on the part of land users who were additionally suffering from disparities in wealth, power, and education. These circumstances often led to ambiguous perceptions and ambivalent feelings of those involved toward the utility of the abstract and intangible currency of knowledge. Additionally, the academic landscape and its internal (and at times competitive) division and incentive structures was found to favor disciplinary, career-oriented, fast-track strategies and behavior on the part of the scientists involved, rather than fostering a more corporate, collective approach. Knowledge exchange and communication were often experienced as cumbersome extra obligations and inputs without clear personal output or benefits, i.e., as a risk rather than a pleasure. These are some of the framing conditions for cooperative knowledge production in sustainability projects that have been described as a social dilemma of transdisciplinarity (Schmidt and Pröpper 2017); partly similar results have been reported in partner projects in Asia (Siew et al. 2016).

In the light of the approaches being adopted in other nonacademic sustainability research, as sketched above, it can be stated that the present academic sustainability research could profit significantly from opening up to artistic contributions. These contributions include additional and previously unexplored ways of representing and communicating results, as illustrated by the examples of participatory scenario painting (Johansson and Isgren 2017) or of the Beehive Design Collective, and as highlighted by many other practical examples of emerging art representations in Africa (Savage 2014, Herz et al. 2015, Holm and Kallehauge 2015). Beyond this creative potential of art for representational purposes, we should consider the "inspirational capacities that can activate behavioural changes, policy reform and custodial care," as Weintraub (2012) has outlined. The key challenge that artists such as Allen have formulated, i.e., "to break through prejudice, apathy, economic pressures and blind spots to catalyze a transformation of culture, attitudes, and behaviours" (Allen 2015:26), certainly applies to the TFO project outlined as an example. Beyond the very fundamental question of whether scientific knowledge is sufficient and adequate for finding solutions to pressing and difficult problems (Rittel and Webber 1973) such as sustainable land-use adaptation in times of globalization, the question remains whether academic knowledge contains the dimensions of knowledge that are required to catalyze change and break circuits of tragedy. Art's contribution to social action could focus on experimental, imaginative, and experiential types and processes of knowledge, generating interactions with threatened parts of ecosystems as processes in which real-time repercussions can be witnessed directly, in the sense suggested by Neal (2015) as well as Ringel (2013) and Jeremijenko (Weintraub 2015).

\section{DISCUSSION}

The way in which I have embedded sustainability science within a wider comparative context, through a comparison with activities in the fields of art-and-sustainability, art-and-science, and science for sustainability, has revealed that there may well be some added value in encouraging an artistic sustainability science. Likewise, it has exposed shortcomings in the current (limited methods of) communication and representation of scientific findings, as well as some deeper crises in the fields of agency and imagination, and knowledge and reality.

The first crisis has been aptly formulated by the artist Jeremijenko (https://www.ted.com/talks/natalie jeremijenko the art of the eco mindshift/transcript): "What the climate crisis has revealed to us is a secondary, more insidious and more pervasive crisis, which is the crisis of agency, which is what to do. Somehow buying a local lettuce, changing a light bulb, driving the speed limit, changing your tires regularly, doesn't seem sufficient in the face 
of climate crisis." One might add that somehow writing another paper, attending another conference, particpating dispassionately in transdisciplinarity does not seem sufficient in the face of a manifest disconnect between sustainability knowledge and social action, between science and the users of scientific results. The potential answers that art might contribute to approach this crisis of agency point at a clear underuse of manifold means of representation, and even more so of imagination, and, as in the case of Jeremijenko, also a need to make more creative use of technology, to experiment, re-experience, and rethink processual human-environment relationships that offer an additonal opportunity to break circuits of lethargy and to prompt a change in behavior. This is not meant to focus only on individualized agency, but also to include blind spots in policy making as well.

The second crisis is related and might be labeled the need for additional knowledge recognition and production. As heterogeneous as the contributing disciplines of sustainability science may be, they are "problem-driven, with the goal of creating and applying knowledge in support of decision making for sustainable development" (Clark and Dickson 2003:8059). As has been outlined, a classical understanding of knowledge as a body of true statements, objective propositions, and descriptions of the world, that is, knowledge about things, is only part of the picture of research. In addition to this, knowing as a process of constant inquiry, involving "the body, especially our sensorymotor processes and our emotions and feelings, in our capacity for understanding and knowing," has been emphasized (Johnson 2010:145). Such knowledge is "tacit, practical, nondiscursive, sensory knowledge, as embodied in artistic products and processes" (Borgdorff 2009:3). Such knowing is deeply rooted in experience, and art, in addition to the scientific description of a situation or phenomenon, is able to present or enact its experiential qualities, meanings, emotions, and values, which are equally needed for perceiving and acting (Brewer 2002). In light of these arguments, the suggestion to open sustainability science to contributions from art and artistic research (Johnson 2010, Borgdorff 2011) seems justified, and examples of how to start have been presented.

Beyond this, we are facing what might also be labeled a crisis of classic models of reality and realism, "deficits in reality" (Göltenboth 2015), a quest for "better realities," as Katherine Carl termed it in an interview with Linda Weintraub (Weintraub 2015), the "rupture between imagination and real life" as Ingold (2014) calls it, or even the entire redefinition of an inquiry into our modernist existence, as envisioned by Latour in his collaborations with artists (Latour 2013, Thoreau et al. 2016). The encounters between artistic and scientific modes of knowledge production show us that reality is complex, textured (Klingan et al. 2015), and layered (Pröpper 2015b). Instead of bounded disciplines and mononaturalistic options for action, we need collective approaches to problem formulation that involve understanding the interlinkages between physical, emotional, sensual, bodily, and discursive parts and processes of politicized realities, and which involve art.

\section{CONCLUSION}

Sustainability science is facing a crisis of agency and collaborative knowledge production. The field would strongly benefit from appropriating and experimenting with types of imaginative agency, knowledge, and research that can be provided by art. Ultimately, science and art are linked through their quest for fundamental understanding, a practice that is as dedicated to "broadening our perspectives and enriching our minds as it is to enriching our world with new images, narratives, sounds and experiences" (Borgdorff 2011:16).

By offering a concise overview and comparison of exemplary activities in the fields of art-and-sustainability, art-and-science, and science and sustainability, I have shown that art contributions involve an experimental and experiential approach to knowledge production that explicitly includes processual, affective, and sensory types of knowledge and forms of interaction. On a more pragmatic level, I have argued that artists could be partners in inter- and transdisciplinarity, as well as stakeholders functioning as a cultural consciousness.

It goes without saying that this analysis from an anthropological perspective will not lead to an all-encompassing attempt at the reconcilitation of two very diverse fields. There are highly specialized subfields that continue to operate largely without directly affecting one another, but if more contact occurred between them, it could lead to important results. However, there are emerging arguments to challenge the historical and hierarchical perspective that artistic ways of knowledge production and artistic research are not taken seriously enough in the world of genuine scientific research (Borgdorff 2009).

Connecting knowledge, morality, beauty, and everyday life in the making as constitutive elements of sustainable behavior, the possibilities of a contribution of art to sustainable science are only beginning to be tapped and are far from being sufficiently understood or represented.

Responses to this article can be read online at: http://www.ecologyandsociety.org/issues/responses. php/9359

\section{Acknowledgments:}

Parts of this article grounding on empirical work emerged from research made possible by The Future Okavango project (www. future-okavango.org) funded by the German Federal Ministry of Education and Research (01LL0912A).

\section{LITERATURE CITED}

Abel, T., and J. R. Stepp. 2003. A new ecosystems ecology for anthropology. Conservation Ecology 7(3):12. http://dx.doi. org/10.5751/ES-00579-070312

Allen, P. 2015. The extraordinary story of human beings and energy. Pages 21-26 in L. Neal, editor. Playing for time: making art as if the world mattered. Oberon, London, UK.

Bateman, I. J., A. R. Harwood, G. M. Mace, R. T. Watson, D. J. Abson, B. Andrews, A. Binner, A. Crowe, B. H. Day, S. Dugdale, C. Fezzi, J. Foden, D. Hadley, R. Haines-Young, M. Hulme, A. Kontoleon, A. A. Lovett, P. Munday, U. Pascual, J. Paterson, G. Perino, A. Sen, G. Siriwardena, D. van Soest, and M. Termansen. 2013. Bringing ecosystem services into economic decision- 
making: land use in the United Kingdom. Science 341 (6141):45-50. http://dx.doi.org/10.1126/science.1234379

Baxstrom, R., T. Meyers, and P. Quinn, editors. 2008. Anthropologies. Creative Capitalism, Baltimore, Maryland, USA.

Berger, K. 2006. The artist as a mad scientist. Salon 22 June 2006. [online] URL: http://www.salon.com/2006/06/22/natalie/

Berkes, F., J. Colding, and C. Folke, editors. 2002. Navigating social-ecological systems: building resilience for complexity and change. Cambridge University Press, Cambridge, UK. http://dx. doi.org/10.1017/CBO9780511541957

Bettencourt, L. M. A., and J. Kaur. 2011. Evolution and structure of sustainability science. Proceedings of the National Academy of Sciences 108(49):19540-19545. http://dx.doi.org/10.1073/pnas.1102712108

Bishop, C. 2012. Artificial hells: participatory art and the politics of spectatorship. Verso, London, UK.

Blanes, R., A. Flynn, M. Maskens, and J. Tinius. 2016. Special Issue. Micro-utopias: anthropological perspectives on art, relationality, and creativity. Cadernos de Arte e Antropologia 5(1).

Borgdorff, H. 2009. Artistic research within the fields of science. Bergen Academy of the Arts, Bergen, Norway.

Borgdorff, H. 2011. The production of knowledge in artistic research. Pages 44-63 in M. Biggs and H. Karlsson, editors. The Routledge companion to research in the arts. Routledge, London, UK. http://dx.doi.org/10.4324/9780203841327.ch3

Borucke, M., D. Moore, G. Cranston, K. Gracey, K. Iha, J. Larson, E. Lazarus, J. C. Morales, M. Wackernagel, and A. Galli. 2013. Accounting for demand and supply of the biosphere's regenerative capacity: the National Footprint Accounts' underlying methodology and framework. Ecological Indicators 24:518-533. http://dx.doi.org/10.1016/j.ecolind.2012.08.005

Brewer, D. D. 2002. Supplementary interviewing techniques to maximize output in free listing tasks. Field Methods 14 (1):108-118. http://dx.doi.org/10.1177/1525822X02014001007

Brightman, M., and J. Lewis. 2017. Introduction: the anthropology of sustainability: beyond development and progress. Pages 1-34 in M. Brightman and J. Lewis, editors. The anthropology of sustainability: beyond development and progress. Palgrave Macmillan, New York, New York, USA.

Büscher, B., W. Dressler, and R. Fletcher, editors. 2014. Nature ${ }^{\mathrm{TM}}$ Inc.: environmental conservation in the neoliberal age. University of Arizona Press, Tucson, Arizona, USA.

Caradonna, J. L. 2014. Sustainability: a history. Oxford University Press, Oxford, UK.

Carrier, J. G., and P. West, editors. 2009. Virtualism, governance and practice: vision and execution in environmental conservation. Berghahn, New York, New York, USA.

Carrithers, M. 1990. Is anthropology art or science? Current Anthropology 31(3):263-282. [online] URL: http://www.jstor.org/ stable/2743629

Clark, W. C., and N. M. Dickson. 2003. Sustainability science: the emerging research program. Proceedings of the National
Academy of Sciences 100(14):8059-8061. http://dx.doi.org/10.1073/ pnas. 1231333100

Clifford, J. 1988. The predicament of culture: twentieth-century ethnography, literature, and art. Harvard University Press, Cambridge, Massachusetts, USA.

Clifford, J., and G. E. Marcus, editors. 1986. Writing culture: the poetics and politics of ethnography. University of California Press, Berkeley, California, USA.

Coles, A., editor. 2001. Site-specificity: the ethnographic turn. Black Dog, London, UK.

Cox, R., A. Irving, and C. Wright, editors. 2016. Beyond text? Critical practices and sensory anthropology. Manchester University Press, Manchester, UK.

Daily, G. C., editor. 1997. Nature's services: societal dependence on natural ecosystems. Island Press, Washington, D.C., USA.

Daily, G. C., and P. A. Matson. 2008. Ecosystem services: from theory to implementation. Proceedings of the National Academy of Sciences 105(28):9455-9456. http://dx.doi.org/10.1073/ pnas.0804960105

Daily, G. C., S. Polasky, J. Goldstein, P. M. Kareiva, H. A. Mooney, L. Pejchar, T. H. Ricketts, J. Salzman, and R. Shallenberger. 2009. Ecosystem services in decision making: time to deliver. Frontiers in Ecology and the Environment 7(1):21-28. http://dx.doi.org/10.1890/080025

de Groot, R., L. Brander, S. van der Ploeg, R. Costanza, F. Bernard, L. Braat, M. Christie, N. Crossman, A. Ghermandi, L. Hein, S. Hussain, P. Kumar, A. McVittie, R. Portela, L. C. Rodriguez, P. ten Brink, and P. van Beukering. 2012. Global estimates of the value of ecosystems and their services in monetary units. Ecosystem Services 1(1):50-61. http://dx.doi. org/10.1016/j.ecoser.2012.07.005

Descola, P. 2013. Beyondnature and culture. University of Chicago Press, Chicago, Illinois, USA.

Domptail, S., and O. Mundy. 2013. Okavango basin - relative importance of ecosystem services (ESS) among stakeholders. Biodiversity and Ecology 5(1):37-42. http://dx.doi.org/10.7809/be.00241

Einzig, B., editor. 1996. Thinking about art: conversations with Susan Hiller. Manchester University Press, Manchester, UK.

Elliott, D., and D. Culhane, editors. 2016. A different kind of ethnography: imaginative practices and creative methodologies. University of Toronto Press, Toronto, Canada.

Eppink, F. V., A. Werntze, S. Mäs, A. Popp, and R. Seppelt. 2012. Land management and ecosystem services: how collaborative research programmes can support better policies. Gaia 21 (1):55-63. https://doi.org/10.14512/gaia.21.1.14

Fabian, J. 2014. Time and the other: how anthropology makes its object. Columbia University Press, New York, New York, USA. http://dx.doi.org/10.7312/fabi16926

Finley, S., and J. G. Knowles. 1995. Researcher as artist/artist as researcher. Qualitative Inquiry 1(1):110-142. http://dx.doi. org/10.1177/107780049500100107 
Foster, H. 1995. The artist as ethnographer? Pages 302-309 in G. E. Marcus and F. R. Myers, editors. The traffic in culture: refiguring art and anthropology. University of California Press, Berkeley, California, USA.

Fuchs, D. A., and S. Lorek. 2005. Sustainable consumption governance: a history of promises and failures. Journal of Consumer Policy 28(3):261-288. http://dx.doi.org/10.1007/ $\underline{\mathrm{s} 10603-005-8490-\mathrm{Z}}$

Funtowicz, S. O., and J. R. Ravetz. 1995. Science for the post normal age. Pages 146-161 in L. Westra and J. Lemons, editors. Perspectives on ecological integrity. Springer, Dordrecht, The Netherlands.

Gablik, S. 1997. Conversations before the end of time. Thames and Hudson, New York, New York, USA.

Gell, A. 1998. Art and agency: an anthropological theory. Clarendon, Oxford, UK.

Giddens, A. 1979. Central problems of sociological theory: action, structure and contradiction in social analysis. University of California Press, Berkeley, California, USA.

Göltenboth, N. 2015. "I am the instrument that people might play" - participation and collaboration in contemporary art from Havana. Ethnoscripts 17(1):58-73.

Grimshaw, A., and A. Ravetz. 2015. The ethnographic turn - and after: a critical approach towards the realignment of art and anthropology. Social Anthropology 23(4):418-434. http://dx.doi. org/10.1111/1469-8676.12218

Grunwald, A. 2004. Strategic knowledge for sustainable development: the need for reflexivity and learning at the interface between science and society. International Journal of Foresight and Innovation Policy 1(1-2):150-167. http://dx.doi.org/10.1504/ $\underline{\text { IJFIP.2004.004619 }}$

Grunwald, A. 2014. Sustainable consumption - the life-saving straw in the matter of sustainability? Gaia 23(S1):145-145. https:// doi.org/10.14512/gaia.23.S1.1

Grunwald, A. 2015. Transformative Wissenschaft - eine neue Ordnung im Wissenschaftsbetrieb? Gaia 24(1):17-20. https://doi. org/10.14512/gaia.24.1.5

Herz, M., H. Focketyn, I. Schröder, and J. Jamrozik, editors. 2015. African modernism: the architecture of independence: Ghana, Senegal, Côte D'Ivoire, Kenya, Zambia. Park Books, Zurich, Switzerland.

Heuson, J. 2015. On hearing together critically: making aural politics sensible through art and ethnography. Ethnoscripts 17 (1):74-95.

Hiller, S. 1996. Art and anthropology/anthropology and art (1977). Pages 16-25 in B. Einzig, editor. Thinking about art: conversations with Susan Hiller. Manchester University Press, Manchester, UK.

Hirsch Hadorn, G., D. Bradley, C. Pohl, S. Rist, and U. Wiesmann. 2006. Implications of transdisciplinarity for sustainability research. Ecological Economics 60(1):119-128. http://dx.doi.org/10.1016/j.ecolecon.2005.12.002
Hoekstra, A. Y., and T. O. Wiedmann. 2014. Humanity's unsustainable environmental footprint. Science 344(6188):1114-1117. http://dx.doi.org/10.1126/science.1248365

Holling, C. S., and L. H. Gunderson. 2002. Resilience and adaptive cycles. Pages 25-62 in L. H. Gunderson and C. S. Holling, editors. Panarchy: understanding transformations in human and natural systems. Island Press, Washington, D.C., USA.

Holm, M. J., and M. M. Kallehauge, editors. 2015. Africa: architecture, culture, identity. Louisiana Museum of Modern Art and contributors, Humlebæk, Denmark.

Howes, D. 2003. Sensual relations: engaging the senses in culture and social theory. University of Michigan Press, Ann Arbor, Michigan, USA. http://dx.doi.org/10.3998/mpub.11852

Ingold, T. 2000. The perception of the environment: essays on livelihood, dwelling and skill. Routledge, London, UK.

Ingold, T. 2001. Beyond art and technology: the anthropology of skill. Pages 17-32 in M. B. Schiffer, editor. Anthropological perspectives on technology. University of New Mexico Press, Albuquerque, New Mexico, USA.

Ingold, T. 2007. Lines: a brief history. Routledge, London, UK.

Ingold, T. 2008. Anthropology is not ethnography. Proceedings of the British Academy 154:69-92. http://dx.doi.org/10.5871/ bacad/9780197264355.003.0003

Ingold, T. 2010. The textility of making. Cambridge Journal of Economics 34(1):91-102. http://dx.doi.org/10.1093/cje/bep042

Ingold, T. 2013. Making: anthropology, archaeology, art and architecture. Routledge, London, UK.

Ingold, T. 2014. That's enough about ethnography! HAU: Journal of Ethnographic Theory 4(1):383-395. http://dx.doi.org/10.14318/ $\underline{\text { hau4.1.021 }}$

Ingold, T. 2016. From science to art and back again: the pendulum of an anthropologist. Anuac 5(1):5-23. http://dx.doi.org/10.7340/ anuac2239-625X-2237

Ingold, T., and E. Hallam. 2007. Creativity and cultural improvisation: an introduction. Pages 1-24 in E. Hallam and T. Ingold, editors. Creativity and cultural improvisation. Berg, Oxford, UK.

Jackson, M. 1998. Minima ethnographica: intersubjectivity and the anthropological project. University of Chicago Press, Chicago, Illinois, USA.

Jackson, T. 2006. The Earthscan reader in sustainable consumption. Earthscan, London, UK.

Johansson, E. L., and E. Isgren. 2017. Local perceptions of landuse change: using participatory art to reveal direct and indirect socioenvironmental effects of land acquisitions in Kilombero Valley, Tanzania. Ecology and Society 22(1):3. http://dx.doi. org/10.5751/ES-08986-220103

Johnson, M. 2010. Embodied knowing through art. Pages 141-151 in M. Biggs and H. Karlsson, editors. The Routledge companion to research in the arts. Routledge, London, UK. http:// dx.doi.org/10.4324/9780203841327.ch8 
Kara, H. 2015. Creative research methods in the social sciences: a practical guide. Policy Press, Bristol, UK. http://dx.doi. org/10.2307/j.ctt1t88xn4

Kates, R. W. 2011. What kind of a science is sustainability science? Proceedings of the National Academy of Sciences 108 (49):19449-19450. http://dx.doi.org/10.1073/pnas.1116097108

Kester, G. H. 2011. The one and the many: contemporary colaborative art in a global context. Duke University Press, Durham, North Carolina, USA. http://dx.doi.org/10.1215/9780$\underline{822394037}$

Klingan, K., A. Sepahvand, C. Rosol, and B. M. Scherer, editors. 2015. Textures of the anthropocene: grain vapor ray. MIT Press, Cambridge, Massachusetts, USA.

Komiyama, H., and K. Takeuchi. 2006. Sustainability science: building a new discipline. Sustainability Science 1(1):1-6. http:// dx.doi.org/10.1007/s11625-006-0007-4

Kosuth, J. 1991. The artist as anthropologist. Pages 107-128 in J. Kosuth, editor. Art after philosophy and after: collected writings, 1966-1990. MIT Press, Cambridge, Massachusetts, USA.

Lammer, C., K. Sawchuk, L. Cartwright, and T. Tembeck. 2012. Empathography. Löcker, Vienna, Austria.

Latour, B. 2002. Iconoclash: Gibt es eine Welt jenseits des Bilderkrieges? Merve, Berlin, Germany.

Latour, B. 2013. An inquiry into modes of existence: an anthropology of the moderns. Harvard University Press, Cambridge, Massachusetts, USA.

Latour, B. 2017. Anthropology at the time of the Anthropocene: a personal view of what is to be studied. Pages 35-49 in $\mathrm{M}$. Brightman and J. Lewis, editors. The anthropology of sustainabililty: beyond development and progress. Palgrave MacMillan, New York, New York, USA. http://dx.doi. org/10.1057/978-1-137-56636-2 2

Lenton, T. M., H. Held, E. Kriegler, J. W. Hall, W. Lucht, S. Rahmstorf, and H. J. Schellnhuber. 2008. Tipping elements in the Earth's climate system. Proceedings of the National Academy of Sciences 105(6):1786-1793. http://dx.doi.org/10.1073/pnas.0705414105

Lindenfeld, L. A., D. M. Hall, B. McGreavy, L. Silka, and D. Hart. 2012. Creating a place for environmental communication research in sustainability science. Environmental Communication 6(1):23-43. http://dx.doi.org/10.1080/17524032.2011.640702

Lockyer, J., and J. R. Veteto, editors. 2013. Environmental anthropology engaging ecotopia: bioregionalism, permaculture, and ecovillages. Berghahn, New York, New York, USA.

Marcus, G. E., and F. R. Myers, editors. 1995. The traffic in culture: refiguring art and anthropology. University of California Press, Berkeley, California, USA.

Miller, A. I. 2014. Colliding worlds: how cutting-edge science is redefining contemporary art. Norton, New York, New York, USA.

Miller, D., editor. 2005. Materiality. Duke University Press, Durham, North Carolina, USA.
Miller, T. R. 2013. Constructing sustainability science: emerging perspectives and research trajectories. Sustainability Science 8 (2):279-293. http://dx.doi.org/10.1007/s11625-012-0180-6

Myers, W. 2015. Bio Art: altered realities. Thames and Hudson, London, UK.

Neal, L. 2015. Playing for time: making art as if the world mattered. Oberon, London, UK.

Norgaard, R. B. 2010. Ecosystem services: from eye-opening metaphor to complexity blinder. Ecological Economics 69 (6):1219-1227. http://dx.doi.org/10.1016/j.ecolecon.2009.11.009

Oldeland, J., C. Erb, M. Finckh, and N. Jürgens. 2013. Special volume: environmental assessments in the Okavango region. Biodiversity and Ecology 5:1-418. http://dx.doi.org/10.7809/b-e. vol 05

Ostrom, E. 2009. A general framework for analyzing sustainability of social-ecological systems. Science 325 (5939):419-422. http://dx.doi.org/10.1126/science.1172133

Pedersen, D. B., and V. F. Hendricks. 2014. Science bubbles. Philosophy and Technology 27(4):503-518. http://dx.doi. org/10.1007/s13347-013-0142-7

Pink, S. 2009. Doing sensory ethnography. Sage, Thousand Oaks, California, USA. http://dx.doi.org/10.4135/9781446249383

Pink, S., P. Hubbard, M. O’Neill, and A. Radley. 2010. Walking across disciplines: from ethnography to arts practice. Visual Studies 25(1):1-7. http://dx.doi.org/10.1080/14725861003606670

Popa, F., M. Guillermin, and T. Dedeurwaerdere. 2015. A pragmatist approach to transdisciplinarity in sustainability research: from complex systems theory to reflexive science. Futures 65:45-56. http://dx.doi.org/10.1016/j.futures.2014.02.002

Pröpper, M. 2015a. Emerging markets for nature and the challenges for the ecosystem service approach. Development and Change 46(2):247-268. http://dx.doi.org/10.1111/dech.12153

Pröpper, M. 2015b. Shifting patterns, zooming layers, focusing processes. Art and anthropology in a transforming and translucent world. Ethnoscripts 17(1):5-22.

Pröpper, M., A. Gröngröft, M. Finckh, S. Stirn, V. De Cauwer, F. Lages, W. Masamba, M. Murray-Hudson, L. Schmidt, B. Strohbach, and N. Jürgens, editors. 2015. The future Okavango: findings, scenarios, and recommendations for action. Research Project Final Synthesis Report 2010-2015. University of Hamburg, Hamburg, Germany. [online] URL: http://www. future-okavango.org/downloads/TFO_Report_engl_compiled_small version.pdf

Pröpper, M., and F. Haupts. 2014. The culturality of ecosystem services. Emphasizing process and transformation. Ecological Economics 108:28-35. http://dx.doi.org/10.1016/j.ecolecon.2014.09.023

Pröpper, M., and C. Lammer. 2015. Empathografie. Ein Dialog. Ethnoscripts 17(1):218-227.

Ramos, M. J. 2015. Stop the academic world, I wanna get off in the Quai de Branly. Of sketchbooks, museums and anthropology. Cadernos de Arte e Antropologia 4(2):141-178. [online] URL: https://cadernosaa.revues.org/989 
Ringel, F. 2013. Epistemic collaborations in contexts of change: on conceptual fieldwork and the timing of anthropological knowledge. Laboratorium: Russian Review of Social Research 5 (2). [online] URL: http://www.soclabo.org/index.php/laboratorium/ article/view/82/866

Rittel, H. W. J., and M. M. Webber. 1973. Dilemmas in a general theory of planning. Policy Sciences 4(2):155-169.

Rockström, J., W. Steffen, K. Noone, Å. Persson, F. S. Chapin III, E. F. Lambin, T. M. Lenton, M. Scheffer, C. Folke, H. J. Schellnhuber, B. Nykvist, C. A. de Wit, T. Hughes, S. van der Leeuw, H. Rodhe, S. Sörlin, P. K. Snyder, R. Costanza, U. Svedin, M. Falkenmark, L. Karlberg, R. W. Corell, V. J. Fabry, J. Hansen, B. Walker, D. Liverman, K. Richardson, P. Crutzen, and J. A. Foley. 2009. A safe operating space for humanity. Nature 461:472-475. http://dx.doi.org/10.1038/461472a

Röder, A., M. Pröpper, M. Stellmes, A. Schneibel, and J. Hill. 2015. Assessing urban growth and rural land use transformations in a cross-border situation in northern Namibia and southern Angola. Land Use Policy 42:340-354. http://dx.doi.org/10.1016/j. landusepol.2014.08.008

Rutten, K., A. van Dienderen, and R. Soetaert. 2013. Revisiting the ethnographic turn in contemporary art. Critical Arts 27 (5):459-473. http://dx.doi.org/10.1080/02560046.2013.855513

Savage, P., editor. 2014. Making art in Africa 1960-2010. Lund Humphries, Farnham, UK.

Scheffer, M., J. Bascompte, T. K. Bjordam, S. R. Carpenter, L. B. Clarke, C. Folke, P. Marquet, N. Mazzeo, M. Meerhoff, O. Sala, and F. R. Westley. 2015. Dual thinking for scientists. Ecology and Society 20(2):3. http://dx.doi.org/10.5751/ES-07434-200203

Schmidt, L., and M. Pröpper. 2017. Transdisciplinarity as a realworld challenge: a case study on a North-South collaboration. Sustainability Science 12(3):365-379. http://dx.doi.org/10.1007/ $\underline{\mathrm{s} 11625-017-0430-8}$

Schnegg, M., R. Rieprich, and M. Pröpper. 2014. Culture, nature, and the valuation of ecosystem services in northern Namibia. Ecology and Society 19(4):26. http://dx.doi.org/10.5751/ ES-06896-190426

Schneider, A. 2008. Three modes of experimentation with art and ethnography. Journal of the Royal Anthropological Institute 14 (1):171-194. http://dx.doi.org/10.1111/j.1467-9655.2007.00484.x

Schneider, A., and C. Wright, editors. 2006. Contemporary art and anthropology. Berg, Oxford, UK.

Schneider, A., and C. Wright, editors. 2010. Between art and anthropology: contemporary ethnographic practice. Berg, Oxford, UK.

Schneider, A., and C. Wright, editors. 2013. Anthropology and art practice. Bloomsbury, London, UK.

Schoolman, E. D., J. S. Guest, K. F. Bush, and A. R. Bell. 2012. How interdisciplinary is sustainability research? Analyzing the structure of an emerging scientific field. Sustainability Science 7 (1):67-80. http://dx.doi.org/10.1007/s11625-011-0139-z
Siew, T. F., T. Aenis, J. H. Spangenberg, A. Nauditt, P. Döll, S. K. Frank, L. Ribbe, B. Rodriguez-Labajos, C. Rumbaur, J. Settele, and J. Wang. 2016. Transdisciplinary research in support of land and water management in China and Southeast Asia: evaluation of four research projects. Sustainability Science 11(5):813-829. http://dx.doi.org/10.1007/s11625-016-0378-0

Smith, C. 2010. What is a person? Rethinking humanity, social life, and the moral good from the person up. University of Chicago Press, Chicago, Illinois, USA.

Ssorin-Chaikov, N. 2013. Ethnographic conceptualism. Laboratorium: Russian Review of Social Research 5(2):5-18. [online] URL: http://www.soclabo.org/index.php/laboratorium/ article/view/336/822

Steffen, W., Å. Persson, L. Deutsch, J. Zalasiewicz, M. Williams, K. Richardson, C. Crumley, P. Crutzen, C. Folke, L. Gordon, M. Molina, V. Ramanathan, J. Rockström, M. Scheffer, H. Schellnhuber, and U. Svedin. 2011. The Anthropocene: from global change to planetary stewardship. Ambio 40(7):739-761. http://dx.doi.org/10.1007/s13280-011-0185-X

Stern, P. C. 2000. New environmental theories: toward a coherent theory of environmentally significant behavior. Journal of Social Issues 56(3):407-424. http://dx.doi.org/10.1111/0022-4537.00175

Strohm, K. 2012. When anthropology meets contemporary art: notes for a politics of collaboration. Collaborative Anthropologies 5(1):98-124. http://dx.doi.org/10.1353/cla.2012.0004

Svasek, M. 2007. Anthropology, art and cultural production. Pluto, London, UK.

Thoreau, F., A. d'Hoop, A. Amat, J. Grosman, G. Laki, P. Lefebvre, and E. Maury. 2016. Reset inquiry! Pages 455-467 in B. Latour, editor. Reset modernity! MIT Press, Cambridge, Massachusetts, USA.

Vaage, N. S. 2016. What ethics for bioart? NanoEthics 10 (1):87-104.

Weintraub, L. 2012. To life! Eco art in pursuit of a sustainable planet. University of California Press, Berkeley, California, USA.

Weintraub, L. 2015. Curator - anthropologist/ethnographer artist. Katherine Carl and Natalie Jeremijenko interviewed by Linda Weintraub. Ethnoscripts 17(1):198-217.

Wesseling, J., editor 2011. See it again, say it again: the artist as researcher. Valiz Wimby, Amsterdam, The Netherlands.

Westmoreland, M. R. 2011. Ethnography + art: convergence or collision? Ibraaz 001/1 June 2011. [online] URL: http://www. ibraaz.org/essays/11

Wilson, S., editor. 2013. Art+science now. Thames and Hudson, New York, New York, USA.

Wimmer, A. 2005. Kultur als Prozess: Zur Dynamik des Aushandelns von Bedeutungen. VS-Verlag für Sozialwissenschaften, Wiesbaden, Germany. http://dx.doi.org/10.1007/978-3-322-80663-5 